\title{
Microbial degradation of lignocellulosic biomass: discovery of novel natural lignocellulolytic bacteria
}

\author{
Shabbir Ahmed, Md Siddiqur Rahman, Md Mahmudul hasan, Nilanjana Paul, Abu Ashfaqur Sajib * \\ Department of Genetic Engineering and Biotechnology, University of Dhaka, Dhaka, Bangladesh
}

\begin{abstract}
Lignocellulosic biomass is the most abundant biomaterial on Earth and holds enormous potential as a source of fermentable sugars for cost-effective biofuel production. The main obstacle is the intractable and convoluted structure and composition of lignocellulosics which are mainly made of lignin, cellulose and hemicellulose. However, nature has equipped microbes with enzymes that can deconstruct lignocellulose and release fermentable sugars. In this study, we selected bacteria (belonging to 6 different genera) from nature that had been grown in minimal culture media with cellulose or lignin as the sole carbon source, and assessed their lignocellulolytic activities in qualitative and quantitative assays. Through sequence analysis of the $16 \mathrm{~S}$ rRNA gene, we discovered a novel lignocellulolytic bacterial species, Chryseobacterium gleum, capable of degrading both cellulose and lignin. In addition, a few other bacterial species previously known to degrade either cellulose or lignin were found to have lignocellulolytic activities. The majority of these bacterial species were found to produce extracellular lignocellulolytic enzymes. Lignocellulolytic bacteria identified in this study may serve as sources of genes/enzymes which might find applications in biofuel production and other industrial applications.
\end{abstract}

Key words: biofuel, lignocellulosic biomass, cellulose, lignin, lignocellulolytic bacteria

\section{Introduction}

The global consumption of fossil fuels (coal, gas and oil) is over 20 billion tons per year (BP Energy Outlook2017). In the International Energy Outlook 2016 report, the U.S. Energy Information Administration (EIA) projected a $48 \%$ increase in the world energy consumption rate by 2040 . This ever-increasing demand for energy, rapid depletion of fossil fuel reserves, global warming and associated climatic changes have brought the issue of fuel production from renewable sources to the forefront of discussions worldwide (Yoshikawa et al., 2013; Zhang et al., 2010; Tiwari et al., 2013; Talebnia et al., 2010). One of the most promising alternatives to fossil fuels is biofuel, which is derived through the conversion of biomass (Huang et al., 2013; Talebnia et al., 2010; Ooi et al., 2004). Many countries have already set specific goals in their national strategies to adopt biofuel for sustainable development (Zhang et al., 2010; Abbas and Ansumali, 2010; Viikari et al., 2012).

Lignocellulosic biomass is the most abundant and renewable natural resource on Earth (Zhang et al., 2010; Zhou et al., 2011). The net photosynthetic production of dry lignocellulosic biomass by plants on Earth has been estimated to be 155 billion tons per year (Talebnia et al., 2010). Lignocellulosics from sources other than food, therefore, can provide significant economic and strategic benefits for the production of biofuel (Viikari et al., 2012). This not only offers a cost-effective way to tackle the energy crisis, but it also means that it may be possible to manage environmental issues accrued from lignocellulosic waste accumulation and carbon dioxide emissions (Zhang et al., 2010; Zhou et al., 2011).

Lignocellulose is primarily composed of cellulose, hemicellulose and lignin (Yoshikawa et al., 2013; Zhou

\footnotetext{
* Corresponding author: Department of Genetic Engineering and Biotechnology, University of Dhaka, Dhaka, Bangladesh; e-mail: abu.sajib@du.ac.bd
} 
et al., 2011). In general, lignocellulosic biomass contains approximately $35-50 \%$ of cellulose, $20-35 \%$ of hemicellulose, and 10-25\% of lignin (Zhou et al., 2011). Cellulose is an organic polymer of D-glucose units connected through $\beta(1 \rightarrow 4)$ glycosidic bonds, while hemicelluloses contain many different sugar monomers (Murphy and McCarthy, 2005; Zhou et al., 2011). These can be used as a cheap and easily available source of fermentable sugars to produce biofuel. Cellulose and hemicellulose present in the plant cell wall remain tightly bound to lignin, which is a complex of chemically heterogeneous high molecular weight polymers composed of alkylphenol units (Huang et al., 2013; Yoshikawa et al., 2013; Talebnia et al., 2010). Lignin is highly recalcitrant to degradation and forms a physical barrier to biological and chemical hydrolysis of cellulose and hemicellulose (Huang et al., 2013; Yoshikawa et al., 2013; Talebnia et al., 2010; Nobre and Aanen, 2012; Woo et al., 2014; Bandounas et al., 2011). Therefore, lignin must be broken efficiently before fermentable sugars can be liberated to make biofuel production from lignocellulose economically viable.

Although several physicochemical pretreatment technologies have been developed to disrupt the noncellulosic matrix to render cellulose and hemicellulose more accessible for enzymatic hydrolysis, these pretreatment technologies are generally expensive, require significant energy inputs and long reaction times, and/or generate compounds that are inhibitory to fermentation in the subsequent step (Huang et al., 2013; Bandounas et al., 2011; Talebnia et al., 2010). Efficient but cost-effective methods for selective lignin degradation are, therefore, in high demand (de Gonzalo et al., 2016; Huang et al., 2013). Enzymatic hydrolysis offers a more specific and effective alternative for lignin depolymerization as well as cellulose degradation (Bandounas et al., 2011). Moreover, enzymatic breakdown generally takes place under milder conditions with lower energy inputs and fewer negative environmental impacts (Bandounas et al., 2011; Huang et al., 2013).

A number of fungi are known to produce lignocellulose degrading enzymes (Ponnambalam et al., 2011; Woo et al., 2014). However, the use of fungi requires more time and means a higher cost of enzyme production, purification and engineering compared to bacterial use (Huang et al., 2013; Ponnambalam et al., 2011; Woo et al., 2014; Taylor et al., 2012). The discovery of novel lignocellulolytic bacteria may constitute the source of novel enzymes to be used in biofuel production and other industrial applications. In this study, we isolated and identified bacteria from nature which can degrade both lignin and cellulose.

\section{Materials and methods}

\section{Sources of bacteria}

Soil from dumping areas for domestic kitchen wastes (Ramna area, Dhaka, Bangladesh), decaying plant material in garden soil (Curzon Hall area, University of Dhaka), cow dung and woodworm gut were used as the starting materials to isolate and characterize lignocellulolytic bacteria. $1 \mathrm{~g}$ of each of the soil samples and cow dung were mixed together and the volume was made up to $30 \mathrm{ml}$ with the addition of sterile $0.9 \%(\mathrm{w} / \mathrm{v}) \mathrm{NaCl}$ solution. The suspension was mixed by mild vortexing and incubated at $35^{\circ} \mathrm{C}$ for 30 minutes. Woodworm gut was macerated separately in $0.9 \%(\mathrm{w} / \mathrm{v}) \mathrm{NaCl}$ solution under sterile conditions, mixed by mild vortexing and incubated at $35^{\circ} \mathrm{C}$ for 30 minutes. After incubation, clearer solutions from the top were collected, mixed and serially diluted $\left(10^{-1}\right.$ to $10^{-5}$ times) with $0.9 \%(\mathrm{w} / \mathrm{v}) \mathrm{NaCl}$ solution.

\section{Selection and screening of cellulose degrading bacteria}

$100 \mu \mathrm{l}$ of each dilution was inoculated in a minimal liquid culture medium $\left(\mathrm{NaCl} 6.0 \mathrm{~g} / \mathrm{l},\left(\mathrm{NH}_{4}\right)_{2} \mathrm{SO}_{4} 1 \mathrm{~g} / \mathrm{l}\right.$, $\mathrm{KH}_{2} \mathrm{PO}_{4} 0.5 \mathrm{~g} / \mathrm{l}, \mathrm{K}_{2} \mathrm{HPO}_{4} 0.5 \mathrm{~g} / \mathrm{l}, \mathrm{MgSO}_{4} 0.1 \mathrm{~g} / \mathrm{l}$ and $\mathrm{CaCl}_{2} \cdot 2 \mathrm{H}_{2} \mathrm{O} 0.1 \mathrm{~g} / 1$ ) with carboxymethyl cellulose (CMC) $(0.1 \%(\mathrm{w} / \mathrm{v}))(039-01335$, Wako Chemicals) as the sole carbon source and incubated at $35^{\circ} \mathrm{C}$ for $72 \mathrm{~h}$ at $140 \mathrm{rpm}$. Following bacterial growth, $100 \mu \mathrm{l}$ of culture was spread on a solid selection medium $(\mathrm{NaCl} 6 \mathrm{~g} / \mathrm{l}$, $\left(\mathrm{NH}_{4}\right)_{2} \mathrm{SO}_{4} 1 \mathrm{~g} / \mathrm{l}, \mathrm{KH}_{2} \mathrm{PO}_{4} 0.5 \mathrm{~g} / \mathrm{l}, \mathrm{K}_{2} \mathrm{HPO}_{4} 0.5 \mathrm{~g} / \mathrm{l}, \mathrm{MgSO}_{4}$ $0.1 \mathrm{~g} / \mathrm{l}, \mathrm{CaCl}_{2} \cdot 2 \mathrm{H}_{2} \mathrm{O} 0.1 \mathrm{~g} / \mathrm{l}, \mathrm{CMC} 0.1 \%(\mathrm{w} / \mathrm{v})$ and $1.5 \%$ agar (w/v)) and incubated at $35^{\circ} \mathrm{C}$ for $72 \mathrm{~h}$. Well separated colonies with different morphological characteristics were sub-cultured on LB-agar medium (LB 2.0\% (w/v) and $1.5 \%$ agar $(\mathrm{w} / \mathrm{v}))$ and incubated at $35^{\circ} \mathrm{C}$ for $48 \mathrm{~h}$.

Selected pure cultures of bacterial samples were grown separately in liquid media $\left(\mathrm{NaCl} 6 \mathrm{~g} / 1,\left(\mathrm{NH}_{4}\right)_{2} \mathrm{SO}_{4}\right.$ $1 \mathrm{~g} / 1, \mathrm{KH}_{2} \mathrm{PO}_{4} 0.5 \mathrm{~g} / \mathrm{l}, \mathrm{K}_{2} \mathrm{HPO}_{4} 0.5 \mathrm{~g} / \mathrm{l}, \mathrm{MgSO}_{4} 0.1 \mathrm{~g} / \mathrm{l}$ and $\left.\mathrm{CaCl}_{2} \cdot 2 \mathrm{H}_{2} \mathrm{O} 0.1 \mathrm{~g} / \mathrm{l}\right)$ with Whatman ${ }^{\circledR}$ grade1 filter paper (1001 110, GE Healthcare-Whatman), which is made of cellulose, as the only source of carbon. In this assay, 12 pieces of $\sim 0.04 \mathrm{~mm}^{2}$ sized sterilized Whatman ${ }^{\circledR}$ filter 
papers were added to $5 \mathrm{ml}$ of medium in each tube. The cultures were incubated at $35^{\circ} \mathrm{C}$ for $48 \mathrm{~h}$ in an incubator at $140 \mathrm{rpm}$. The growth of bacteria was compared to the control culture medium without bacterial inoculation.

\section{Qualitative analyses of cellulolytic activity}

Qualitative analyses of cellulolytic activity of selected bacterial samples were performed using the Congo Red zone clearing assay (Kaur and Arora, 2012; Behera et al., 2014; Ponnambalam et al., 2011). In the first approach, selected bacteria were cultured on CMC-LB-agar media $(\mathrm{CMC} 0.1 \%(\mathrm{w} / \mathrm{v}), \mathrm{LB} 2.0 \%(\mathrm{w} / \mathrm{v})$ and agar $1.5 \%(\mathrm{w} / \mathrm{v}))$ at $35^{\circ} \mathrm{C}$ for $48 \mathrm{~h}$ and then flooded with $0.1 \%$ (w/v) Congo Red (0379, Amresco LLC) solution in water. After incubation for $15 \mathrm{~min}$, the culture media were de-stained with $1 \mathrm{M} \mathrm{NaCl}$ solution. In the second approach, the bacteria were inoculated on CMC-LB-agar solid media along with Congo Red (CMC 0.1\% (w/v), LB 2.0\% (w/v), agar $1.5 \%(\mathrm{w} / \mathrm{v})$ and Congo Red $0.1 \%(\mathrm{w} / \mathrm{v}))$ and incubated at $35^{\circ} \mathrm{C}$ for $48 \mathrm{~h}$. The plates were then de-stained with $1 \mathrm{M}$ $\mathrm{NaCl}$ solution.

\section{Quantitative analysis of the production of reducing sugars}

A quantitative analysis of the production of reducing sugars from the hydrolysis of cellulose polysaccharides by bacterial enzymes was performed using 3,5-Dinitrosalicylic acid (DNS) (Ponnambalam et al., 2011; Kaur and Arora, 2012). Briefly, selected bacteria were grown on culture medium $\left(\mathrm{NaCl} 6 \mathrm{~g} / \mathrm{l},\left(\mathrm{NH}_{4}\right)_{2} \mathrm{SO}_{4} 1 \mathrm{~g} / \mathrm{l}, \mathrm{KH}_{2} \mathrm{PO}_{4}\right.$ $0.5 \mathrm{~g} / 1, \mathrm{~K}_{2} \mathrm{HPO}_{4} 0.5 \mathrm{~g} / \mathrm{l}, \mathrm{MgSO}_{4} 0.1 \mathrm{~g} / \mathrm{l}$ and $\mathrm{CaCl}_{2} \cdot 2 \mathrm{H}_{2} \mathrm{O}$ $0.1 \mathrm{~g} / \mathrm{l})$ containing Whatman ${ }^{\circledR}$ grade 1 filter paper (1001 110 , GE Healthcare-Whatman) strips of $6 \mathrm{~cm}^{2}(\sim 50 \mathrm{mg})$. Then, the cultures were incubated for 48 hours at $35^{\circ} \mathrm{C}$ in an incubator at $140 \mathrm{rpm}$. Optical densities (OD) of all cultures at $600 \mathrm{~nm}$ were equalized to the culture with the lowest OD using phosphate buffered saline (PBS) $\left(\mathrm{NaCl} 8 \mathrm{~g} / 1, \mathrm{KCl} 0.2 \mathrm{~g} / 1, \mathrm{Na}_{2} \mathrm{HPO}_{4} 1.44 \mathrm{~g} / 1\right.$ and $\mathrm{KH}_{2} \mathrm{PO}_{4}$ $0.24 \mathrm{~g} / \mathrm{l}, \mathrm{pH}$ 7.4). The cultures were centrifuged at $2000 \times \mathrm{g}$ for $5 \mathrm{~min}$ and supernatants (culture media) were collected from each of the cultures. $1 \mathrm{ml}$ of the supernatants was mixed with $2 \mathrm{ml}$ of water and $3 \mathrm{ml}$ of DNS in test tubes and boiled for 5 min. Once cooled, $1 \mathrm{ml}$ of sodium potassium tartrate (also known as Rochelle salt) $(40 \% \mathrm{w} / \mathrm{v})$ solution was added to each tube and ODs were measured at $540 \mathrm{~nm}$ using a spectrophotometer. The concentration of reducing sugars in the samples was measured and compared to those of standard glucose solutions.

\section{Screening for ligninolytic activity}

Bacterial samples primarily selected on CMC-minimal medium were inoculated in another medium (Kraft lignin $0.25 \mathrm{~g} / \mathrm{l}, \mathrm{KH}_{2} \mathrm{PO}_{4} 0.25 \mathrm{~g} / \mathrm{l}, \mathrm{CaCl}_{2} \cdot 2 \mathrm{H}_{2} \mathrm{O} 0.01 \mathrm{~g} / \mathrm{l}$, $\mathrm{MgSO}_{4} 0.25 \mathrm{~g} / \mathrm{l}, \mathrm{NaCl} 0.1 \mathrm{~g} / \mathrm{l},\left(\mathrm{NH}_{4}\right)_{2} \mathrm{SO}_{4} 1.0 \mathrm{~g} / \mathrm{l}$ and agar 1.5\% (w/v)), in which Kraft-lignin (Sc-489763, Santa Cruz Biotechnology, Inc.) was used as the sole carbon source, and these were then incubated at $35^{\circ} \mathrm{C}$ for 7 days.

The ligninolytic activity of these bacterial samples was analyzed using 2,2'-Azino-bis(3-ethylbenzthiazoline6-sulfonic acid) (ABTS) (Mabrouk et al., 2010; Floch et al., 2007; Huang et al., 2013). This assay was performed following 2 different approaches. In the qualitative approach, the bacteria were cultured on a medium containing ABTS (LB 2.0\% (w/v), agar 1.5\% (w/v), ABTS $1.0 \%(\mathrm{w} / \mathrm{v})$, and $\left.\mathrm{CuSO}_{4} 0.1 \mathrm{~g} / \mathrm{l}\right)$ at $35^{\circ} \mathrm{C}$ for 48 hours. Following incubation, the appearance of a greenish color surrounding the cultures was observed. In the relativequantitative approach, the bacterial samples were cultured in tryptone-yeast extract broth (Tryptone $0.5 \%(\mathrm{w} / \mathrm{v})$ and yeast extract $0.3 \%(\mathrm{w} / \mathrm{v}))$ and incubated for $48 \mathrm{~h}$ at $35^{\circ} \mathrm{C}$ in a shaking incubator at $140 \mathrm{rpm}$. Optical densities (OD) of all cultures at $600 \mathrm{~nm}$ were equalized using PBS to the culture with the lowest OD. The cultures were centrifuged at $2000 \times \mathrm{g}$ for $5 \mathrm{~min}$ and supernatants (culture media) were collected from each of the cultures. Cell pellets were suspended in $5 \mathrm{ml}$ of cold PBS and lysed by sonication. Cell extracts were collected following centrifugation at $8400 \times \mathrm{g}$ for $10 \mathrm{~min}$. Optical densities of the cell extracts at $280 \mathrm{~nm}$ were equalized using PBS to the extract with the lowest OD. $150 \mu \mathrm{l}$ of ABTS solution along with $50 \mu \mathrm{l}$ of the cell extracts or supernatants (culture media) were added to the wells in a 96-well plate. ABTS solutions were prepared fresh at $\mathrm{pH} 4,5$ and 6 using PBS. After vigorous mixing, absorption at $420 \mathrm{~nm}$ was measured in a micro-plate spectrophotometer at $1 \mathrm{~min}$ intervals for $3 \mathrm{~min}$ and compared to the controls.

\section{Identification of bacteria by $16 \mathrm{~S}$ rRNA gene sequencing}

The bacterial samples were cultured in LB broth at $35^{\circ} \mathrm{C}$ in a shaking incubator for $24 \mathrm{~h}$. The cultures were centrifuged at $5000 \mathrm{rpm}$ for $5 \mathrm{~min}$ and the pellets were 
washed twice with phosphate buffered solution (PBS). The pellets were mixed with $150 \mu \mathrm{l}$ of $10 \%(\mathrm{w} / \mathrm{v})$ of Chelex ${ }^{\circledR}-100$ (C7901, Sigma) in sterile water and vortexed vigorously for $10 \mathrm{~s}$. The suspensions were incubated at $95^{\circ} \mathrm{C}$ for $20 \mathrm{~min}$, vortexed again and then centrifuged at $14000 \times \mathrm{g}$ for $10 \mathrm{~min}$. The supernatants were collected and quantified for DNA in a spectrophotometer. The amount of $0.5 \mu \mathrm{l}$ of the DNA samples ( $100 \mathrm{ng})$ were mixed with $2.5 \mu \mathrm{l}$ of $10 \times$ PCR buffer, $1.5 \mu \mathrm{l}$ of dNTP mix (10 mM), $0.75 \mu \mathrm{l}$ of each forward (16S_357F: CTCCTA CGGGAGGCAGCAG) and reverse (16S_1100R: AGGGT TGCGCTCGTTG) primers $(10 \mu \mathrm{M}), 18.8 \mu \mathrm{l}$ of nucleasefree water and $0.2 \mu \mathrm{l}$ of Taq DNA polymerase (EP0702, Thermo Fisher Scientific). The sequences were amplified in a thermal cycler under the following conditions: an initial denaturation step at $94^{\circ} \mathrm{C}$ for $3 \mathrm{~min}$., then $30 \mathrm{cy}$ cles - each with denaturation at $94^{\circ} \mathrm{C}$ for $30 \mathrm{~s}$, annealing at $58^{\circ} \mathrm{C}$ for $1 \mathrm{~min}$., and elongation at $72^{\circ} \mathrm{C}$ for $1 \mathrm{~min}$., followed by the final extension at $72^{\circ} \mathrm{C}$ for $5 \mathrm{~min}$. The amplified products were resolved in $1.2 \%(\mathrm{w} / \mathrm{v})$ agarose gels using $1 \times$ Tris Acetate EDTA (TAE) buffer along with a DNA size marker (300003, GeneON). Amplified DNA sequences were visualized in a gel documentation system following incubation with ethidium bromide in $1 \times$ TAE buffer. PCR products were purified using FavorPrep ${ }^{\mathrm{TM}}$ GEL/PCR Purification Kit (FAGCK 001, Favorgen Biotech Corp.) following the manufacturer's protocol. Purified PCR products were sequenced following the Sanger sequencing technique at $1^{\text {st }}$ Base DNA Sequencing Services, Malaysia. The bacteria were identified by comparing the sequences in the databases using the Basic Local Alignment Search Tool (BLAST) on the National Center for Biotechnology Information (NCBI) website.

\section{Data analysis}

The data were analyzed using Microsoft Excel and GraphPad Prism (version 6.1) software. All data are presented as a mean \pm standard error of mean (SEM).

\section{Results and discussion}

The deconstruction of lignin to enhance the release of fermentable sugars from plant cell walls presents a major challenge for biofuel production from lignocellulosic biomass. Nature has devised ways to degrade lignocellulosic biomass via microbes (de Gonzalo et al.,
2016). These microbes can be used as sources of enzymes for industrial applications to effectively degrade lignocellulosic biomasses for biofuel production. In this study, lignocellulolytic microorganisms with potential abilities to degrade cellulose and/or lignin were selected from various natural sources, as the microbes present in decaying leaves, in garden soil and in household wastes, or living in the guts of organisms that thrive on lignocellulosic biomasses are supposed to have lignocellulolytic enzymes (Dubey et al., 2014; Ahmad et al., 2013).

Our study was based on the premise that if bacteria were allowed to grow in a minimal medium containing cellulose as the sole carbon source, then only those bacteria capable of utilizing cellulose would survive. As cellulose is insoluble in a culture medium, in this study carboxymethyl cellulose (CMC) was used as an alternative substrate (Ponnambalam et al., 2011; Anand et al., 2009; Behera et al., 2014). CMC, an amorphous and esterified form of cellulose, is considered a perfect ana$\log$ for assessing cellulolytic activities (Ponnambalam et al., 2011).

Bacteria belonging to 6 different genera were selected in minimal media, with $\mathrm{CMC}$ as the sole carbon source (Fig. 1). Pursuant to the homology of $16 \mathrm{~S}$ rRNA gene sequences to those in the database repositories, these bacteria belonged to Acinetobacter spp., Klebsiella variicola, Chryseobacterium gleum, Bacillus spp., Proteus mirabilis and Stenotrophomonas maltophilia (Table 1). 16S ribosomal RNA gene (16 $\mathrm{SRNA}$ ) sequence analysis is a standard approach to identify bacteria (Bandounas et al., 2011; Klindworth et al., 2013). At the species level and on the basis of $16 \mathrm{~S}$ rRNA gene sequences, 4 bacterial species ( $K$. variicola, $C$. gleum, $A$. baumannii, $P$. mirabilis, and $S$. maltophilia) were identified (Table 1). Using this approach, the identity of the 2 remaining lignocellulolytic bacteria (A. calcoaceticus/pittii and B. pumilus/ altitudinis/stratosphericus/xiamenensis) could not be resolved at the species level, although the query sequences found $100 \%$ identical matches to several sequences in database repositories. These sequences have been reposited and are available at GenBank, NCBI (accession numbers: MG738223, MG738224, MG738225, MG 738226, MG738227, MG738228 and MG738229).

All selected bacteria, except for $P$. mirabilis, grew in minimal media, with Kraft-lignin as the only carbon source. Similar to an earlier report (Prasad et al., 2014), we, too, observed a slow growth of bacteria. In fact, the 

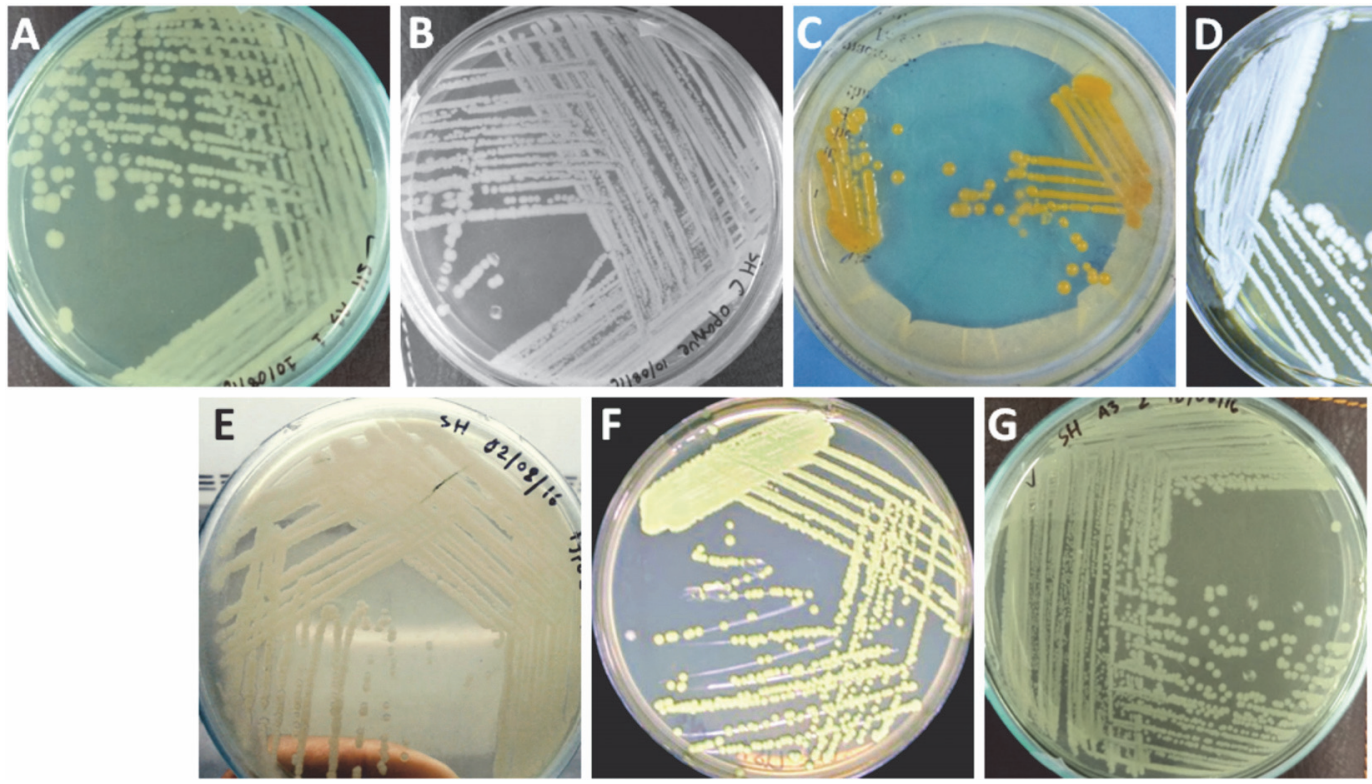

Fig. 1. Bacteria selected on minimal media with carboxymethyl cellulose (CMC) as the sole carbon source; six different bacterial genera with distinct morphological characteristics could grow in minimal media using CMC as the only carbon source; this figure shows culture of the selected bacteria on LB-Agar medium; A) A. calcoaceticus/pittii, B) $K$. variicola, C) C. gleum, D) Bacillus spp.,

E) A. baumannii, F) $P$. mirabilis, and G) S. maltophilia

Table 1. Identification of the CMC-minimal medium selected bacteria based on 16S rRNA gene sequence homology

\begin{tabular}{l|c|c|c}
\hline \multicolumn{1}{c|}{ Bacterial spp. } & $\begin{array}{c}\text { Query size, } \\
\text { bps }\end{array}$ & $\begin{array}{c}\text { Query } \\
\text { coverage }\end{array}$ & Identity \\
\hline $\begin{array}{l}\text { Acinetobacter spp. } \\
\text { (possible species are A. calcoaceticus and A. pittii) }\end{array}$ & 705 & $100 \%$ & $100 \%$ \\
\hline Klebsiella variicola & 607 & $100 \%$ & $100 \%$ \\
\hline Chryseobacterium gleum & 681 & $100 \%$ & $100 \%$ \\
\hline Acinetobacter baumannii & 700 & $100 \%$ & $100 \%$ \\
\hline Stenotrophomonas maltophilia & 707 & $100 \%$ & $100 \%$ \\
\hline $\begin{array}{l}\text { Bacillus spp. (possible species are B. pumilus, B. altitudinis, } \\
\text { B. stratosphericus, and B. xiamenensis) }\end{array}$ & 689 & $100 \%$ & $100 \%$ \\
\hline Proteus mirabilis & 694 & $100 \%$ & $100 \%$ \\
\hline
\end{tabular}

growth of all tested bacterial species in the Kraft-lignin containing media was much slower when compared to that in the CMC-agar medium. All bacterial samples except Bacillus spp. were negative for Gram-staining (data not shown). Moreover, all of the $\mathrm{CMC}$-selected bacteria grew in media with Whatman ${ }^{\circledR}$ grade 1 filter paper as the sole carbon source. According to the manufacturer, Whatman ${ }^{\circledR}$ grade 1 filter paper (1001 110, GE Healthcare-Whatman) is made of cellulose. The presence of cellulolytic enzymes in bacterial strains was further verified by the Congo Red zone clearing assay and estima- tion of reducing sugars released from the cellulose. These tests are commonly used to assess cellulolytic activities (Ponnambalam et al., 2011; Behera et al., 2014; Anand et al., 2009; Kaur and Arora, 2012). The Congo Red zone clearing assay is a qualitative assay (Ponnambalam et al., 2011) based on the binding of Congo Red to cellulose and its release upon degradation, due to cellulolytic activity (Apun et al., 2000; Teather and Wood, 1982). In our study, clear zones were observed around the colonies of all bacterial species selected on CMC-minimal media (Fig. 2). Cellulolytic activities of 


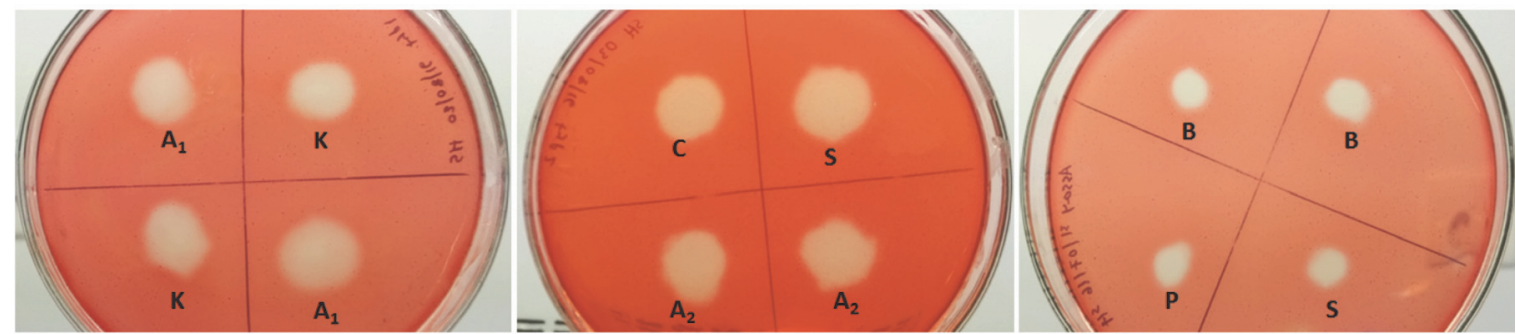

Fig. 2. Congo Red zone clearing assay. Clear zones were observed around the colonies of all CMC-selected bacterial species. A1) A.calcoaceticus/pittii, A2) A. baumannii, K) K. variicola, C) C. gleum, B) Bacillus spp., P) P. mirabilis, and S) $S$. maltophilia

these bacteria were quantitatively assessed by measuring the reducing sugars liberated from the cellulose (Whatman ${ }^{\circledR}$ grade 1 filter paper) using 3,5-dinitrosalicylic acid (DNS) based on the colorimetric method. P. mirabilis liberated the highest amount of reducing sugars from the cellulose (Fig. 3).

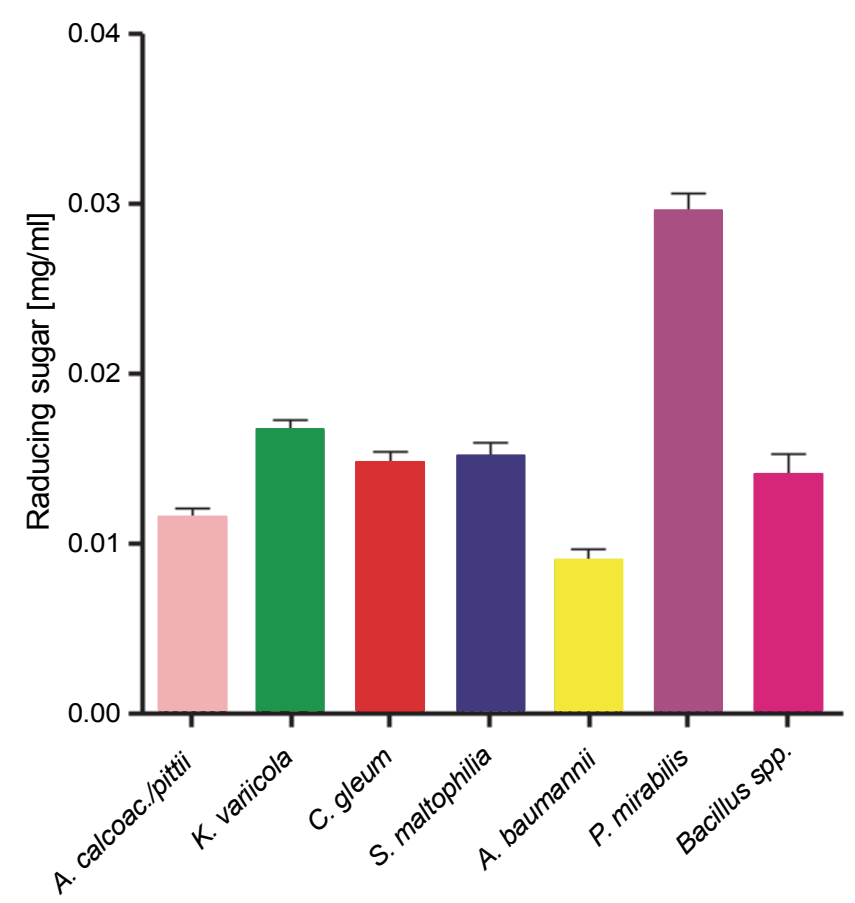

Fig. 3. Quantitation of reducing sugars released from cellulose by bacterial enzymes; $P$. mirabilis released the highest amount of reducing sugars from cellulose; all data are presented as mean \pm standard error of mean (SEM); data represents $\geq 3$ replicates

The cellulolytic bacteria were cultured in minimal media with Kraft-lignin to select those with the ability to utilize Kraft-lignin as the carbon source. Unlike lignin, Kraft-lignin is water-soluble and is used as a carbon source for selection of ligninolytic bacteria (Bandounas et al., 2011; Huang et al., 2013). Acinetobacter spp.,
K. variicola, C. gleum, Bacillus spp. and S. maltophilia grew in minimal media with Kraft-lignin (Fig. 4A). Although $P$. mirabilis exhibited the highest cellulolytic activity, it neither grew in the Kraft-lignin selection medium nor showed ligninolytic activity in other assays.
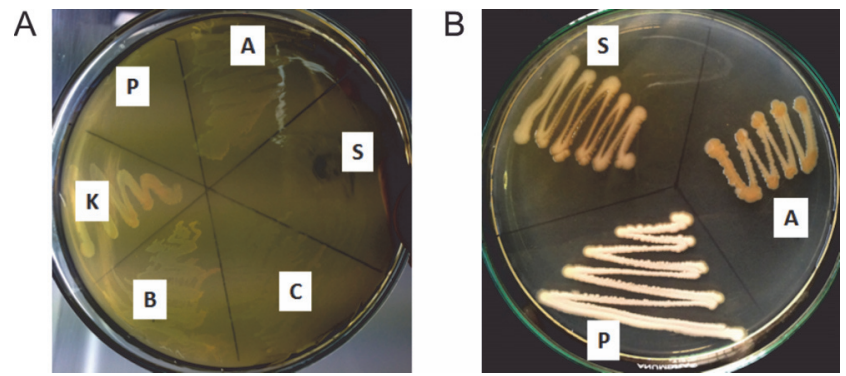

Fig. 4. Ligninolytic activity of bacteria: A) growth of bacteria in minimal media with Kraft-lignin as the only carbon source, B) in ABTS agar media assay greenish color was observed around the ligninolytic bacteria; in this representative image: A) A. calcoaceticus/pittii, B) Bbacillus spp., C) C. gleum, K) $K$. variicola, P) $P$. mirabilis, and S) $S$. maltophilia

2,2'-azino-bis (3-ethylbenzothiazoline)-6-sulphonic acid (ABTS) is a substrate of laccase, an enzyme that can degrade lignin (Huang et al., 2013; Mabrouk et al., 2010). Unlike many oxidoreductases, laccases neither produce toxic hydrogen peroxide as a byproduct nor require the addition of cofactors -- two features which make these enzymes industrially attractive (de Gonzalo et al., 2016). In an ABTS-agar media assay, the greenish color (indicative of laccase activity) was produced around the colonies of all species, except for $P$. mirabilis (Fig. 4B). The relative ligninolytic activities of the bacteria were assessed by measuring the ABTS oxidation level spectrophotometrically. In this assay, the cell extract and culture supernatant of all the CMC-selected bacteria, except $P$. mirabilis, became visibly green fol- 


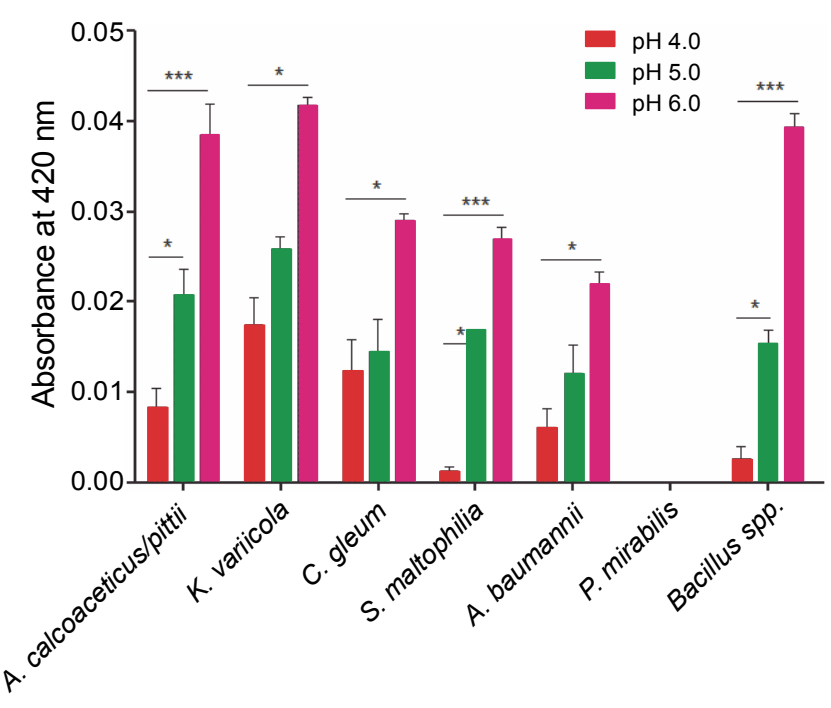

Fig. 5. Bacterial laccase activity at different $\mathrm{pH}$; there was a gradual increase in laccase activity with higher $\mathrm{pH}$; data are presented as mean \pm standard error of mean (SEM) of the activities of extracted intracellular laccase; data represents $\geq 3$ replicates and absorbance was measured after 3 minutes; statistical significances were calculated using t-test (corrected for multiple comparisons using the Holm-Sidak method); ${ }^{*}$ and *** indicate significance at $P<0.05$ and $P<0.0001$, respectively

lowing exposure to ABTS; an increase in absorbance at $420 \mathrm{~nm}$ was also observed. The ABTS-oxidizing activity of the samples was analyzed at $\mathrm{pH} 4,5$ and 6 . All samples showed the highest activities at $\mathrm{pH} 6$ (Fig. 5). The mean laccase activities of $A$. calcoaceticus/pittii, $K$. variicola and Bacillus spp. were greater than those of other bacterial species tested (Fig. 6).

Not all bacteria that can degrade cellulose can also degrade lignin (Bandounas et al., 2011). Many members of the genus Bacillus have been shown to have ligninolytic and/or cellulolytic activities. These include $B$. pumilus, B. brevis, B. alcalophilus, B. subtilis, B. cereus, B. licheniformis, B. circulans, B.atrophaeus, B. halodurans, $B$. tequilensis and $B$. polymyxa (Anand et al., 2009; Dubey et al., 2014; Prasad et al., 2014; Woo et al., 2014; Bandounas et al., 2011; Behera et al., 2014; Ahmad et al., 2013; Huang et al., 2013). K. variicola has been reported to have not only lignocellulolytic activities but also the ability to utilize diverse types of carbohydrates (Jiménez et al., 2014; Dantur et al,. 2015; Islam et al., 2017). A. calcoaceticus and other Acinetobacter members can utilize diesel and lignin as carbon sources (Ho et al., 2017; Ghodake et al., 2009; Ponnambalam et al., 2011). Stenotrophomonas sp. and $P$. vulgaris have been shown to be capable of utilizing cellulose (Anand et al., 2009; Dubey et al., 2014). To date, there has been no published report on the ligninolytic and/or cellulolytic activities of $C$. gleum, nor on the ligninolytic activity of $S$. maltophilia and $P$. mirabilis. It has, however, been previously shown that $S$. maltophilia can degrade crystal violet (Kim et al., 2002), which may be indicative of its ligninolytic activity. In our study, $A$. calcoaceticus/pittii, A. baumannii, $K$. variicola, C. gleum, Bacillus spp., and S. maltophilia were found to have the ability to degrade both lignin and cellulose.

The majority of the bacterial laccases already reported are located intracellularly (Huang et al., 2013; Bandounas et al., 2011; de Gonzalo et al., 2016). Only a few Bacillus species (B. tequilensis, B. atrophaeus and B. pumilus) have been shown to have both intracellular and extracellular laccase activities (de Gonzalo et al., 2016; Huang et al., 2013). In our study, both intra- and extracellular laccase activities of the bacteria were assessed by measuring the oxidation of ABTS. Among the laccasepositive bacteria, all but $C$. gleum showed intra- and extra-cellular activities (Fig. 6). In general, the extracellular laccase activity was relatively small for all tested bacterial species except for Bacillus spp., which showed a higher activity.

In our study, a gradual increase in laccase activity was observed from $\mathrm{pH} 4$ to $\mathrm{pH} 6$ for all bacteria. The $\mathrm{pH}$ for the optimal activity of laccases varies depending on the source of the enzyme. A purified laccase from papaya leaves exhibited a $\mathrm{pH}$ optimum of 6 when measuring oxidation of ABTS (Jaiswal et al., 2015). Fungi grow, in general, at low $\mathrm{pH}$ and produce laccases which work best at acidic pH (2-4) (Kiiskinen et al., 2004; Santhanam et al., 2011). Bacterial laccases have characteristics different to those of their fungal analogs (Huang et al., 2013). The activity of most bacterial laccases (with ABTS) is at its optimum between $\mathrm{pH} 4$ and 6, but some (S. psammoticus) display optimum activity at $\mathrm{pH} 8.5$ (Santhanam et al., 2011). The data presented by Huang and coworkers (2013) showed an inconsistent relationship between $\mathrm{pH}$ and laccase activities from 2 Bacillus species. In the same study, the control laccase from a fungus, Trametes versicolor, showed a higher activity at a lower $\mathrm{pH}$. Laccase activity from Streptomycetes $s p$. has been shown to have a pH optimum at 6 (Demissie and Kumar, 2014). Zhang and coworkers (2012) reported that the efficiency of malachite green decolorization by a laccase 
Intracellular laccase activity

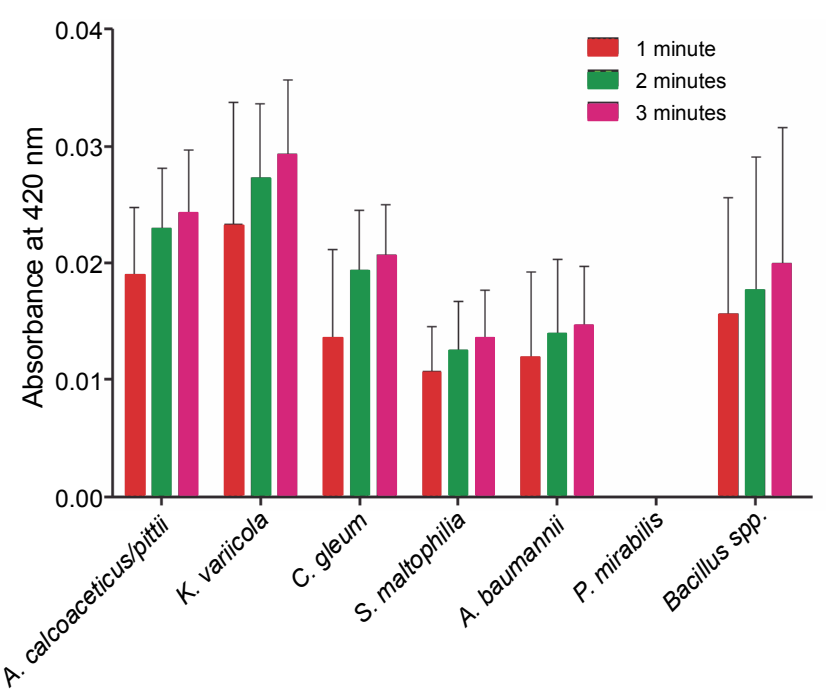

Extracellular laccase activity

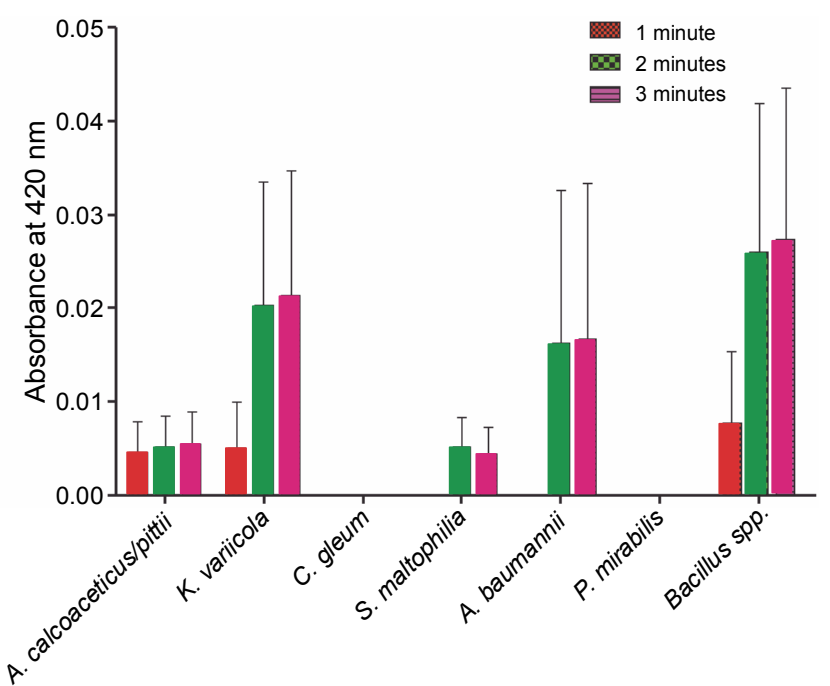

Fig. 6. Intra- and extra-cellular laccase activities of the bacteria; laccase activity was measured at $\mathrm{pH}$ 6.0; mean absorbance due to the oxidation of ABTS by laccases increased gradually with time, though the differences were not statistically significant; overall, Bacillus spp. and $K$. variicola showed higher mean laccase activities; all data are presented as mean \pm standard error of mean (SEM); data represents $\geq 3$ replicates; statistical significances were calculated using t-test (corrected for multiple comparisons using the Holm-Sidak method)

from $B$. vallismortis spores improved as the $\mathrm{pH}$ increased and the maximum efficiency of oxidation of ABTS was obtained at $\mathrm{pH} 6$.

Lignocellulolytic enzymes from bacteria may be used in industrial applications other than biofuel production. Cellulases have applications in starch processing, grain alcohol fermentation, extraction of fruit and vegetable juices, and the textile, pulp and paper industries (Kaur and Arora, 2012). On the other hand, ligninolytic organisms and enzymes can be used for the treatment of xenobiotic compounds (Sivakami et al., 2012). For example, laccases have broad substrate specificities and can oxidize a wide variety of organic and inorganic compounds including dyes in effluents from textile industries (Kiiskinen et al., 2004). Bacterial laccases have been shown to have better characteristics (high temperature, salt, and $\mathrm{pH}$ tolerance) than their fungal counterparts (de Gonzalo et al., 2016; Huang et al., 2013). Lignocellulolytic bacteria identified in this study may, therefore, serve as sources of enzymes which might find applications not only in biofuel production but also in other industrial applications.

\section{Conclusions}

Lignocellulosic biomass holds enormous potential as a source of fermentable sugars for cost-effective biofuel production. In this study, we discovered a novel lignocellulolytic bacterial species, C. gleum, along with 5 other lignocellulolytic bacteria (previously known to degrade either cellulose or lignin) that belong to different genera (Acinetobacter spp., K. variicola, Bacillus spp., P. mirabilis and $S$. maltophilia). Earlier studies have reported better characteristics of bacterial enzymes (high temperature, salt, and $\mathrm{pH}$ tolerance) when compared to their fungal counterparts. Lignocellulolytic bacteria identified in this study may serve as sources of genes and/or enzymes which might find useful industrial applications. These genes may also be engineered to produce enzymes with better functionality and regulation.

\section{Acknowledgements}

This study was financially supported by the Special Allocation for Science and Technology (338-BS (2015-2016) and 121-BS (2016-2017)) awarded to Abu Ashfaqur Sajib by the Ministry of Science and Technology, Bangladesh. The authors would like to thank the Ministry of Science and Technology, Bangladesh for its support.

\section{Conflict of interest}

The authors declare that they have no conflict of interest.

\section{References}

Abbas A., Ansumali S. (2010) Global potential of rice husk as a renewable feedstock for ethanol biofuel production. BioEnergy Res. 3: 328-334. 
Ahmad B., Nigar S., Shah S.S.A., Bashir S., Ali J., Yousaf S., Bangash J.A. (2013) Isolation and identification of cellulose degrading bacteria from municipal waste and their screening for potential antimicrobial activity. World Appl. Sci. J. 27(11): 1420-1426. DOI: 10.5829/idosi.wasj.2013. 27.11.81162.

Anand A.A.P., Vennison S.J., Sankar S.G., Prabhu D.I.G., Vasan P.T., Raghuraman T., Geoffrey C.J., Vendan S.Z. (2009) Isolation and characterization of bacteria from the gut of Bombyx mori that degrade cellulose, xylan, pectin and starch and their impact on digestion. J. Insect Sci. 10: 107.

Apun K., Jong B.C., Salleh M.A. (2000) Screening and isolation of a cellulolytic and amylolytic Bacillus from sago pith waste. J. General Appl. Microbiol. 46(5): 263-267.

Bandounas L., Wierckx N.J.P., de Winde J.H., Ruijssenaars H.J. (2011) Isolation and characterization of novel bacterial strains exhibiting ligninolytic potential. BMC Biotechnology 11: 94-104.

Behera B.C., Parida S., Dutta S.K., Thatoi H.N. (2014) Isolation and identification of cellulose degrading bacteria from Mangrove soil of Mahanadi river delta and their cellulase production ability. Amer. J. Microbiol. Res. 2(1): 41-46. DOI: 10.12691/ajmr-2-1-6.

Dantur K.I., Enrique R., Welin B., Castagnaro A.P. (2015) Isolation of cellulolytic bacteria from the intestine of Diatraea saccharalis larvae and evaluation of their capacity to degrade sugarcane biomass. AMB Express 5: 15.

de Gonzalo G., Colpa D.I., Habib M.H., Fraaije M.W. (2016) Bacterial enzymes involved in lignin degradation. J. Biotech. 236: 110-119. DOI: 10.1016/j.jbiotec.2016.08.011.

Demissie A.G., Kumar A. (2014) Isolation of novel bacteria Isolate from soil for production of extra-cellular laccase enzyme. Inter. J. Emerg. Technol. Adv. Eng. 4(11): 404-407.

Dubey S.K., Meena R.K., Sao S., Patel J., Thakur S., Shukla P. (2014) Isolation and characterization of cellulose degrading bacteria from biogas slurry and their RAPD profiling. Curr. Res. Microb. Biotech. 2(4): 416-421.

Floch C., Alarcon-Gutierrez E., Criquet S. (2007) ABTS assay of phenol oxidase activity in soil. J. Microb. Meth. 71: 319 -324 .

Ghodake G.S., Kalme S.D., Jadhav J.P., Govindwar S.P. (2009) Purification and partial characterization of lignin peroxidase from Acinetobacter calcoaceticus NCIM 2890 and its application in decolorization of textile dyes. Appl. Biochem. Biotechnol. 152(1): 6-14.

Ho M.T., Weselowski B., Y. Ze-C. (2017) Complete genome sequence of Acinetobacter calcoaceticus CA16, a bacterium capable of degrading diesel and lignin. Genome Announc. 5(24): e00494-00417.

Huang X.F., Santhanam N., Badri D.V., Hunter W.J., Manter D.K., Decker S.R., Vivanco J.M., Reardon K.F. (2013) Isolation and characterization of lignin-degrading bacteria from rainforest soils. Biotechnol. Bioeng. 110(6): 1616 $-1626$.

Islam M.A., Karim A., Woon C.W., Ethiraj B., Cheng C.K., Yousuf A., Khan M.M.R. (2017) Augmentation of air ca- thode microbial fuel cell performance using wild type Klebsiella variicola. RSC Adv 7: 4798.

Jaiswal N., Pandey V.P., Dwivedi U.N. (2015) Purification of a thermostable alkaline laccase from papaya (Carica papaya) using affinity chromatography. Int. J. Biol. Macromol. 72: 326-332.

Jiménez D.J., Dini-Andreote F., van Elsas J.D. (2014) Metataxonomic profiling and prediction of functional behaviour of wheat straw degrading microbial consortia. Biotechnol. Biofuels 7: 92.

Kaur M., Arora S. (2012) Isolation and screening of cellulose degrading bacteria in kitchen waste and detecting their degrading potential. IOSR J. Mechan. Civil Eng. 1(2): 33-35.

Kiiskinen L.L., Rättö M., Kruus K. (2004) Screening for novel laccase-producing microbes. J. Appl. Microbiol. 97: 640 -646 .

Kim J.D., Yoon J.H., Park Y.H., Kawai F., Kim H.T., Lee D.W., Kang K.H. (2002) Identification of Stenotrophomonas maltophilia LK-24 and its degradability of Crystal Violet. J. Microbiol. Biotechnol. 12(3): 437-443.

Klindworth A., Pruesse E., Schweer T., Peplies J., Quast C., Horn M., Glockner F.O. (2013) Evaluation of general $16 S$ ribosomal RNA gene PCR primers for classical and nextgeneration sequencing-based diversity studies. Nucl. Acids Res. 41(1): e1. DOI: 10.1093/nar/gks808.

Mabrouk A.M., Kheiralla Z.H., Hamed E.R., Youssry A.A., El Aty A.A.A. (2010) Screening of some marine-derived fungal isolates for lignin degrading enzymes (LDES) production. Agric. Biol. J. North Amer. 1(4): 591-599.

Murphy J.D., McCarthy K. (2005) Ethanol production from energy crops and wastes for use as a transport fuel in Ireland. Appl. Energy 82: 148-166.

Nobre T., Aanen D.K. (2012) Fungiculture or termite husbandry? The ruminant hypothesis. Insects 3(1): 307-323. DOI: 10.3390/insects3010307.

Ooi Y., Zakaria R., Mohamed A.R., Bhatia S. (2004) Catalytic conversion of palm oil-based fatty acid mixture to liquid fuel. Biomass Bioener. 27: 477-484.

Ponnambalam A.S., Deepthi R.S., Ghosh A.R. (2011) Qualitative display and measurement of enzyme activity of isolated cellulolytic bacteria. Biotechnol. Bioinf. Bioeng. 1(1): 33-37.

Prasad M.P., Sethi R., Anand M., Padmavathi T. (2014) Degradation of agrowastes by lignocellulolytic activity of bacterial isolates from marine sources. Asian J. Plant Sci. Res. 4(2): 60-63.

Santhanam N., Vivanco J.M., Decker S.R., Reardon K.F. (2011) Expression of industrially relevant laccases: prokaryotic style. Trends Biotechnol. 29(10): 480-489.

Sivakami V., Ramachandran B., Srivathsan J., Kesavaperumal G., Smily B., Kumar D.J.M. (2012) Production and optimization of laccase and lignin peroxidase by newly isolated Pleurotus ostreatus LIG 19. J. Microbiol. Biotech. Res. 2(6): 875-881.

Talebnia F., Karakashev D., Angelidaki I. (2010) Production of bioethanol from wheat straw: an overview on pretreat- 
ment, hydrolysis and fermentation. Bioresour. Technol. 101(13): 4744-4753. DOI: 10.1016/j.biortech.2009.11. 080.

Taylor C.R., Hardiman E.M., Ahmad M., Sainsbury P.D., Norris P.R., Bugg T.D. (2012) Isolation of bacterial strains able to metabolize lignin from screening of environmental samples. J. Appl. Microbiol. 113(3): 521-530. DOI: 10.1111/j.1365-2672.2012.05352.x.

Teather R.M., Wood P.J. (1982) Use of Congo Red-polysaccharide interactions in enumeration and characterization of cellulolytic bacteria from the bovine rumen. Appl. Environ. Microbiol. 43(4): 777-780.

Tiwari R., Rana S., Singh S., Arora A., Kaushik R., Agrawal V.V., Saxena A.K., Nain L. (2013) Biological delignification of paddy straw and Parthenium sp. using a novel micromycete Myrothecium roridum LG7 for enhanced saccharification. Bioresour. Technol. 135: 7-11.

Viikari L., Vehmaanperä J., Koivula A. (2012) Lignocellulosic ethanol: From science to industry. Biomass Bioener. 46: 13-24. DOI: 10.1016/j.biombioe.2012.05.008

Woo H.L., Hazen T.C., Simmons B.A., DeAngelis K.M. (2014) Enzyme activities of aerobic lignocellulolytic bacteria isolated from wet tropical forest soils. System. Appl. Microbiol. 37(1): 60-67. DOI: 10.1016/j.syapm.2013.10.001.
Yoshikawa T., Yagi T., Shinohara S., Fukunaga T., Nakasaka Y., Tago T., Masuda T. (2013) Production of phenols from lignin via depolymerization and catalytic cracking. Fuel Proces. Technol. 108: 69-75. DOI: 10.1016/j.fuproc.2012. 05.003 .

Zhang C., Diao H., Lu F., Bie X., Wang Y., Lu Z. (2012) Degradation of triphenylmethane dyes using a temperature and $p H$ stable spore laccase from a novel strain of Bacillus vallismortis. Bioresour. Technol. 126: 80-86.

Zhang M., Wang F., Su R., Qi W., He Z. (2010) Ethanol production from high dry matter corncob using fed-batch simultaneous saccharification and fermentation after com bined pretreatment. Bioresour. Technol. 101(13): 4959 -4964 .

Zhang Q., Tian W., Zheng Y., Zhang L. (2010) Fuel consumption from vehicles of China until 2030 in energy scenarios. Energy Policy 38: 6860-6867.

Zhou C.H., Xia X., Lin C.X., Tong D.S., Beltramini J. (2011) Catalytic conversion of lignocellulosic biomass to fine chemicals and fuels. Chem. Soc. Rev. 40(11): 5588-5617. DOI: $10.1039 / \mathrm{c} 1 \mathrm{cs} 15124 \mathrm{j}$. 